\title{
A quantitative study of eosinophil polymorphs in Hodgkin's disease
}

\author{
WJ FUGGLE, J CROCKER, PJ SMITH
}

From the Department of Histopathology, East Birmingham Hospital, Bordesley Green East, Birmingham B9 $5 S T$

SUMMARY Eosinophil polymorphonuclear leucocytes (polymorphs) were counted in 45 specimens from patients with Hodgkin's disease and five specimens from patients with reactive follicular hyperplasia. The use of chlorazol fast pink BK, a little known stain for eosinophil polymorphs, combined with image analysis facilitated rapid and reliable counting. Significant differences were found between the mean percentages of eosinophil polymorphs in the Rye subtypes of Hodgkin's disease. The numbers of eosinophil polymorphs in specimens from patients with reactive follicular hyperplasia were very low and could not be counted.

The tissue of Hodgkin's disease infiltrates is highly polymorphic, containing a wide range of cell types including lymphocytes and macrophages together with epithelioid, Hodgkin, and Reed-Sternberg cells. In addition, eosinophil polymorphonuclear leucocytes (polymorphs) are often present in variable numbers. ${ }^{1-4}$ There is some subjective evidence that the content of eosinophil polymorphs may differ with the Rye subtype of Hodgkin's disease, ${ }^{1} 24$ and in one study ${ }^{3}$ it was suggested that eosinophil polymorphs were more common in biopsy specimens showing fibrosis. In order to obtain objective data, we have examined a series of specimens from patients with Hodgkin's disease and have expressed the number of eosinophil polymorphs present as a percentage of all cells present. This has been facilitated by means of a dye which intensely stains eosinophil granules-namely, chlorazol fast pink. ${ }^{5}$

\section{Material and methods}

\section{PATIENTS AND TISSUES}

All of the cases were taken from the files of East Birmingham Hospital over 12 years. They were classified according to the Rye convention by one of us (JC).

Forty five specimens from 38 patients with Hodgkin's disease were examined. These comprised 15 nodes showing lymphocyte predominance, nine of the nodular sclerosing variety, 14 specimens of mixed cellularity, and seven with lymphocyte deple-

Accepted for publication 25 October 1983 tion. One specimen appeared to show progression from lymphocyte predominance to the nodular sclerosing variety. Five cervical lymph nodes from patients with reactive follicular hyperplasia were also studied. The ages and sexes of the patients concerned are shown in Table 1.

\section{FIXATION AND STAINING}

Specimens were cut into thin slices, fixed at room temperature in $10 \%$ formol-saline for $24-48 \mathrm{~h}$, and routinely processed to paraffin wax. Sections were cut at $4 \mu \mathrm{m}$ thickness and then deparaffinised and stained in $1 \%$ chlorazol fast pink BK (BDH Chemicals Ltd, (Gurr), Atherstone, Warwickshire, England) in 50\% ethanol for $30 \mathrm{~min}$ at room temperature, as described by $\mathrm{Li}$ et al..$^{5}$ Mayer's haemalum was substituted for methyl green as a counterstain. Subsequently, the sections were dehydrated through graded alcohol concentrations, passed through xylene, and mounted in balsam.

\section{COUNTING PROCEDURE}

Counting of cells was greatly facilitated by means of an interactive user controlled image analyser, the Reichert-Jung (Kontron) "Digiplan". This system is closely related to the Reichert-Jung (Kontron) MOP series of analysers, previously described in detail. ${ }^{6-10}$ An image of the section under study was thrown onto the graphic tablet of the Digiplan by means of a projection microscope, using a $40 \times$ objective and $1.25 \times$ projection lens. A simple grid overlay was used on the digitiser tablet to prevent recounting of cells, and a green filter was placed in 
Table 1 Details of specimens from patients with Hodgkins' disease and reactive follicular hyperplasia

\begin{tabular}{|c|c|c|c|c|c|}
\hline Case No & $\begin{array}{l}\text { Age } \\
\text { (yr) }\end{array}$ & $\operatorname{Sex}$ & Site of node & Diagnosis or Rye subtype & $\%$ Eosinophils \\
\hline 1 & 50 & $\mathbf{M}$ & Cervical & Lymphocyte predominant & $0 \cdot 1$ \\
\hline 2 & $?$ & $\mathbf{F}$ & Cervical & Lymphocyte predominant & 0 \\
\hline 3 & 46 & $\mathbf{M}$ & Inguinal & Lymphocyte predominant & 0.6 \\
\hline 4 & 49 & $\mathbf{M}$ & $?$ & Lymphocyte predominant & 0 \\
\hline 5 & 26 & $\mathbf{F}$ & Cervical & Lymphocyte predominant & 0 \\
\hline 6 & 24 & $\mathbf{M}$ & Cervical & Lymphocyte predominant & 0.5 \\
\hline 7 & 24 & $\mathbf{M}$ & Coeliac & Lymphocyte predominant & 0 \\
\hline 8 & 50 & $\mathbf{M}$ & Mediastinum & Lymphocyte predominant & 0.7 \\
\hline 9 & 64 & $\mathrm{~F}$ & Cervical & Lymphocyte predominant & 0 \\
\hline 10 & 25 & $\mathbf{F}$ & Cervical & Lymphocyte predominant & 0.9 \\
\hline 11 & 42 & $\mathbf{M}$ & Axilla & Lymphocyte predominant & 0 \\
\hline${ }^{*} 12$ & 15 & $\mathbf{F}$ & Cervical & Lymphocyte predominant & 0 \\
\hline 13 & 26 & $\mathbf{F}$ & Axilla & Lymphocyte predominant & 0.2 \\
\hline 14 & 47 & $\mathbf{M}$ & Supraclavicular & Lymphocyte predominant & 0 \\
\hline 15 & 15 & $\mathbf{M}$ & Mediastinum & Lymphocyte predominant & $\mathbf{0}$ \\
\hline 15 & 15 & $\ddot{M}$ & Mediastinum & Lymphocyte predominant & 0.8 \\
\hline 1 & 16 & $\mathrm{~F}$ & Cervical & Nodular sclerosis & $7 \cdot 1$ \\
\hline 2 & 68 & $\mathbf{M}$ & Cervical & Nodular sclerosis & $22 \cdot 3$ \\
\hline 3 & 64 & $\mathbf{M}$ & Inguinal & Nodular sclerosis & $15 \cdot 5$ \\
\hline 4 & 50 & $\mathbf{M}$ & Supraclavicular & Nodular sclerosis & 6.7 \\
\hline$* 5$ & 15 & $\mathbf{F}$ & Cervical & Nodular sclerosis & 0 \\
\hline 6 & 17 & $\mathbf{M}$ & Coeliac & Nodular sclerosis & $4 \cdot 2$ \\
\hline 6 & 17 & $\mathbf{M}$ & Coeliac & Nodular sclerosis & $21 \cdot 4$ \\
\hline 7 & 19 & $\mathbf{M}$ & Mediastinum & Nodular sclerosis & $34 \cdot 2$ \\
\hline 8 & 20 & $\mathbf{F}$ & Mediastinum & Nodular sclerosis & 7.6 \\
\hline 1 & 70 & $\mathbf{M}$ & Supraclavicular & Mixed cellularity & 1.4 \\
\hline 2 & 80 & $\mathbf{M}$ & $?$ & Mixed cellularity & $10 \cdot 1$ \\
\hline 3 & 32 & $\mathbf{M}$ & Inguinal & Mixed cellularity & $2 \cdot 3$ \\
\hline 4 & 55 & $\mathbf{M}$ & Cervical & Mixed cellularity & $1 \cdot 2$ \\
\hline 5 & 15 & $\mathbf{M}$ & $?$ & Mixed cellularity & $16 \cdot 8$ \\
\hline 5 & 15 & $\mathbf{M}$ & ? & Mixed cellularity & $\begin{array}{r}10.0 \\
7.9\end{array}$ \\
\hline 5 & 15 & $\mathbf{M}$ & $\dot{?}$ & Mixed cellularity & $\begin{array}{l}7 \cdot 9 \\
6 \cdot 8\end{array}$ \\
\hline 6 & 76 & $\mathbf{M}$ & $?$ & Mixed cellularity & $\begin{array}{l}0 \cdot 8 \\
0\end{array}$ \\
\hline 7 & 51 & $\mathbf{M}$ & Axilla & Mixed cellularity & 0 \\
\hline 8 & 55 & $\mathbf{M}$ & Para-aortic & Mixed cellularity & 3.4 \\
\hline 8 & 55 & $\mathbf{M}$ & Iliac & Mixed cellularity & $\begin{array}{l}3 \cdot 4 \\
0\end{array}$ \\
\hline 9 & 53 & $\mathbf{M}$ & Cervical & Mixed cellularity & $\begin{array}{l}0 \\
0\end{array}$ \\
\hline 10 & 35 & $\mathbf{M}$ & Cervical & Mixed cellularity & $\begin{array}{l}0 \\
4 \cdot 2\end{array}$ \\
\hline 11 & 84 & $\mathbf{F}$ & Axilla & $\begin{array}{l}\text { Mixed cellulanty } \\
\text { Mixed cellularity }\end{array}$ & $\begin{array}{r}4 \cdot 2 \\
20 \cdot 8\end{array}$ \\
\hline 1 & 70 & $\mathbf{M}$ & Supraclavicular & $\begin{array}{l}\text { Mixed cellularity } \\
\text { Lymphocyte depleted }\end{array}$ & $\begin{array}{l}20 \cdot 8 \\
27.0\end{array}$ \\
\hline 2 & 29 & $\mathbf{F}$ & Cervical & $\begin{array}{l}\text { Lymphocyte depleted } \\
\text { Lymphocyte depleted }\end{array}$ & $27 \cdot 0$ \\
\hline 3 & 32 & $\mathbf{F}$ & Cervical & $\begin{array}{l}\text { Lymphocyte depleted } \\
\text { Lymphocyte depleted }\end{array}$ & $18 \cdot 5$ \\
\hline 4 & 26 & $\mathbf{F}$ & Cervical & & $12 \cdot 8$ \\
\hline 4 & 26 & $\mathrm{~F}$ & $\begin{array}{l}\text { Cervical } \\
\text { Cervical }\end{array}$ & Lymphocyte depleted & $31 \cdot 9$ \\
\hline 5 & 18 & $\mathbf{M}$ & $\begin{array}{l}\text { Cervical } \\
\text { Axilla }\end{array}$ & & $8 \cdot 2$ \\
\hline 6 & 63 & $\mathbf{F}$ & $\begin{array}{l}\text { Axilla } \\
\text { Cervical }\end{array}$ & Lymphocyte depleted & $28 \cdot 6$ \\
\hline 1 & 68 & $\mathrm{~F}$ & $\begin{array}{l}\text { Cervical } \\
\text { Cervical }\end{array}$ & Lymphocyte depleted & $31 \cdot 4$ \\
\hline 2 & 4 & $\mathrm{M}$ & Cervical & Reactive follicular hyperplasia & 0 \\
\hline 3 & 6 & $\mathbf{M}$ & Cervical & Reactive follicular hyperplasia & 0 \\
\hline 4 & $?$ & $\mathbf{M}$ & Cervical & Reactive follicular hyperplasia & 0 \\
\hline 5 & 16 & $\mathbf{F}$ & Cervical & Reactive follicular hyperplasia & 0 \\
\hline & & & Cervical & Reactive follicular hyperplasia & 0 \\
\hline
\end{tabular}

${ }^{*}$ Rye subtype appeared to have progressed from lymphocyte predominant to nodular sclerosing disease.

the system to enhance cell contrast. Fields were selected at random as done previously.689 All eosinophils in each field were counted and stored on one channel of the microprocessor, and then all nucleate cells were similarly counted and retained in another channel. About 2000 cells were counted for each specimen, and the numbers of eosinophils were expressed as a percentage of this total count. In the nodular sclerosis subtype, both fibrous and more cellular areas were included in the counting.

\section{Results}

In some cases more than one biopsy specimen was taken from a patient and these are indicated in Table 1, together with the sites from which tissues were removed. In one case, the Rye subtype in a patient appeared to have progressed from lymphocyte predominant to nodular sclerosing disease.

Fig. 1 shows the scatter of percentages of eosinophil polymorphs in all specimens. Eosinophil polymorphs were absent in all of the nodes from patients with reactive follicular hyperplasia. The lymphocyte predominant specimens possessed 0 to $0.9 \%$ eosinophil polymorphs (mean $0.24 \%$ ); the nodular sclerosing nodes 0 to $34.2 \%$ (mean $13 \cdot 2 \%$ ); those with mixed cellularity 0 to $20.8 \%$ (mean $5.35 \%)$; and those showing lymphocyte depletion 


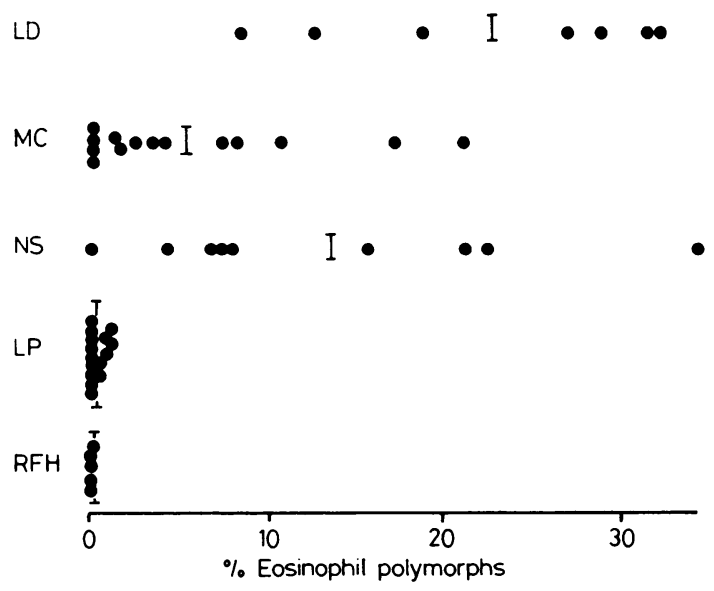

Fig. 1 Mean percentages of eosinophil polymorphs in specimens from patients with Hodgkin's disease (HD) and reactive follicular hyperplasia $(R F H) . L P=$ lymphocyte predominant; $N S=$ nodular sclerosing; $M C=$ mixed cellularity; $L D=$ lymphocyte depleted. Vertical bars show mean of range.

contained 8.2 to $31.9 \%$ eosinophil polymorphs (mean $22.6 \%$ ).

These data, analysed by Student's $t$ test, show significant differences between the various Rye subtypes (Table 2). There was no significant difference, however, between the reactive follicular hyperplasia and lymphocyte predominant Hodgkin's disease specimens.

Fig. 2 and 3 show typical histological preparations of Hodgkin's disease subtypes stained by the chlorazol fast pink technique.

\section{Discussion}

Hodgkin's disease presents a highly polymorphic cellular picture with varying numbers of different cell types. The Rye convention classification depends on the subjective assessment of the relative

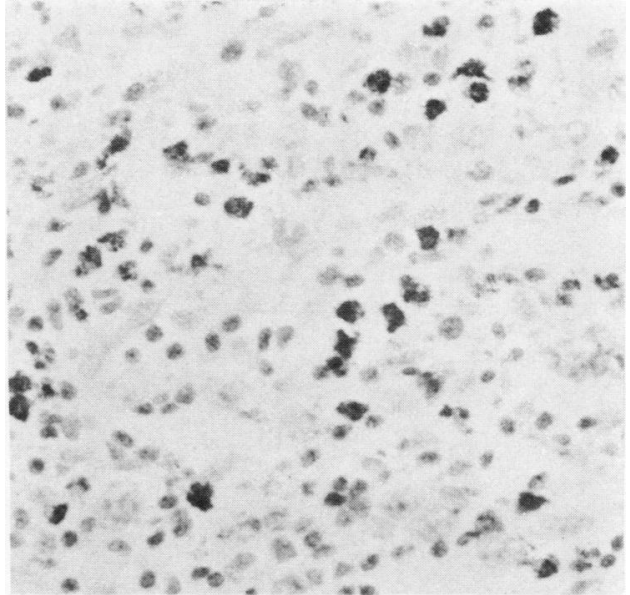

Fig. 2 Numerous darkly stained eosinophil polymorphs in a cellular nodule of nodular sclerosing Hodgkin's disease. Chlorazol fast pink stain with haemalum counterstain. Magnification $\times 180$.

proportions of these and any associated fibrosis to separate Hodgkin's disease into various subtypes, which have prognostic importance. ${ }^{24}$ Few morphometric objective studies have been performed on specimens from patients with Hodgkin's disease,$^{3}{ }^{4} 1112$ and these support the Rye classification only in broad terms.

Livesey et al" performed differential cell counts on nine lymph nodes from patients with Hodgkin's disease using an eyepiece graticule and coverslip marking or clear film grid on the glass slide. They found an implied misnomer in the terminology of the Rye classification, with a higher percentage of lymphocytes in lymphocyte depleted than in mixed cellularity subtypes. They did not distinguish between eosinophil polymorphs and neutrophil polymorphs, counting them as a single category. This totally manual counting technique is extremely laborious as well as labour intensive. The study of Livesey et al is important because it was, to our

Table 2 Significance of differences between Rye subtypes of specimens from patients with Hodgkin's disease and reactive follicular hyperplasia

\begin{tabular}{lllll}
\hline$R F H$ & $L P$ & $N S$ & $M C$ & $L D$ \\
\hline RFH & $0.5>\mathrm{p}>0.1$ & $0.02>\mathrm{p}>0.01$ & $0.1>\mathrm{p}>0.05$ & $\mathrm{p}<0.001$ \\
LP & - & $\mathrm{p}<0.001$ & $0.01>\mathrm{p}>0.001$ & $\mathrm{p}<0.001$ \\
NS & & $0.05>\mathrm{p}>0.02$ & $0.1>\mathrm{p}>0.05$ \\
MC & & - & $\mathrm{p}<0.001$ \\
\hline
\end{tabular}

RFH = reactive follicular hyperplasia.

LP = lymphocyte predominant.

NS = nodular sclerosing

MC = mixed cellularity.

LD = lymphocyte depleted. 


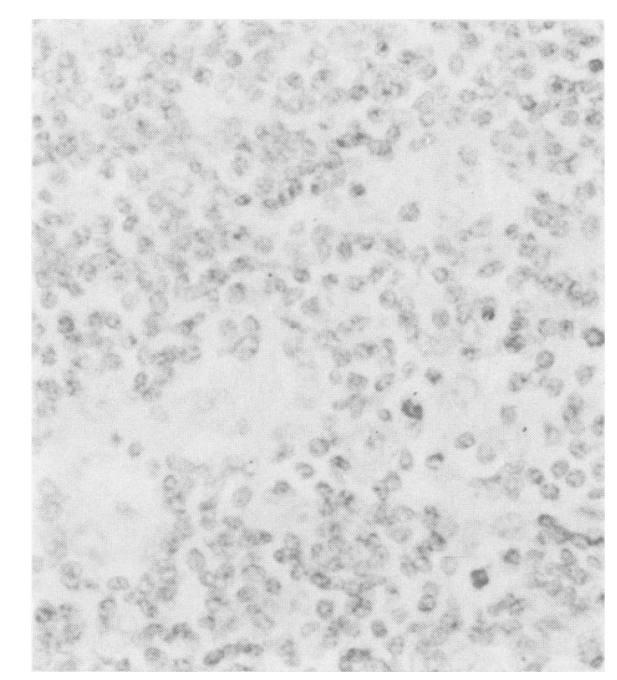

Fig. 3 Specimen of lymphocyte predominant Hodgkin's disease, showing no eosinophil polymorphs. Chlorazol fast pink stain with haemalum counterstain. Magnification $\times 180$.

knowledge, the first recorded morphometric study of Hodgkin's disease.

Toth et $a^{3}$ performed eosinophil polymorph counts on a highly selected group of patients with Hodgkin's disease and found a percertage eosinophil polymorphs of $50 \%$ or more to be associated with a poor prognosis and fibrosis. Their cell counting methods were not described.

Crocker $e t a l^{9}$ performed a quantitative study of $\alpha$-naphthyl acetate esterase positive' cells in 32 specimens from patients with Hodgkin's disease using a similar method to the present study. The cell counts were performed using a graphic tablet linked to a multichannel interactive image analyser (Kontron $\mathrm{MOP} \mathrm{AMO}_{3}$ ) and camera lucida arrangement. $\alpha$-naphthyl acetate esterase is a lysosomal enzyme which is a convenient marker for macrophages. Fewer macrophage type cells were found in mixed cellularity than in nodular sclerosing or lymphocyte depleted subtypes using this histochemical technique. The previous study by Livesey et al" had identified the highest percentage of non-neoplastic mononuclear cells in mixed cellularity on purely morphological grounds. The findings of Crocker et al ${ }^{9}$ were subsequently confirmed using acid phosphatase as a macrophage marker. ${ }^{12}$

Eosinophil polymorphs are relatively easy to distinguish in tissue sections even under low power light microscopy, and their tendency to cluster may lead to misleading impressions of their numbers. The chlorazol fast pink stain, which we used in this study, has been described previously by Japanese workers ${ }^{5}$ but appears to be little used in the UK. The intensity of the staining response enabled the rapid and accurate enumeration of eosinophil polymorphs using the Reichert-Jung (Kontron) "Digiplan".

The results confirm, in broad terms, subjective impressions of numbers of eosinophil polymorphs in Rye subtypes reported by others. ${ }^{1-4}$ There is a distinct difference in eosinophil percentage in the lymphocyte predominant type compared with the nodular sclerosing, mixed cellularity, and lymphocyte depleted varieties. Specimens from patients with reactive follicular hyperplasia contain no countable eosinophil polymorphs. Our study also shows a significant difference between the numbers of eosinophil polymorphs in the four main subtypes of Hodgkin's disease, although there is overlap between groups. There is also variation between different samples from the same patient (Table 1). It has been suggested that the percentage of eosinophil polymorphs is related to age ${ }^{3}$ but we have not found this to be true in our 45 samples. Neither have we found a higher percentage of eosinophil polymorphs in specimens from patients with fibrosis, as previously reported. ${ }^{3}$ The biological importance of these differences is unclear and it is interesting to note that the percentage of eosinophil polymorphs does not exactly mirror prognostic groups, there being a higher mean percentage of eosinophil polymorphs in the nodular sclerosing than in the mixed cellularity subtype. This was also true of $\alpha$-naphthyl acetate esterase positive cells in a previous study. ${ }^{9}$

The role of eosinophil polymorphs in Hodgkin's disease has not been elaborated, although they are often found in areas of necrosis. ${ }^{4}$ We have not seen this on chlorazol fast pink staining. Eosinophil polymorphs are produced in the bone marrow and pass into the tissues after a brief sojourn in the blood stream. They phagocytose particulate matter and have a higher concentration of peroxidase than neutrophil polymorphs. In common with the latter they are attracted by chemotactic lymphokines, ${ }^{13}$ which are, in part at least, released by transformed lymphocytes. It is possible that eosinophil polymorphs are attracted to Hodgkin's disease tissue as a result of the well recognised interaction between, for example, Reed-Sternberg cells and lymphocytes. ${ }^{14}$

As stated by Taylor, ${ }^{15}$ it seems possible that the once popular Gordon biological test ${ }^{16}$ for Hodgkin's disease owed much of its success to eosinophil polymorphs within the sample. In this test suspensions of tissue from patients with Hodgkin's disease were injected intracerebrally and intravenously into rabbits with resulting neurological sequelae with positive samples. 
In view of previous studies of inter-observer disagreemen in the classification of Hodgkin's disease,,$^{17}{ }^{18}$ it is apparent that further morphometric studies of this condition may afford valuable data.

We are grateful to Mrs Pamela Jackson for secretarial assistance and graphics.

\section{References}

' Harrison CV. Lymph node diseases. In: Harrison CV, Weinbren $\mathrm{K}$, eds. Recent advances in pathology, vol 9. Edinburgh: Churchill Livingstone, 1975:77-80.

${ }^{2}$ Butler JJ. The natural history of Hodgkin's disease and its classification. In: Rebuck JW, Berard CW, Abell MR, eds. The reticuloendothelial system. Baltimore: Williams and Wilkins Company, 1975: 184-212.

${ }^{3}$ Tóth J, Dworák O, Sugár J. Eosinophil predominance in Hodgkin's disease. Z Krebsforsch 1977;89:107-11.

${ }^{4}$ Wright DH, Isaacson PG. Biopsy pathology of the lymphoreticular system. London: Chapman and Hall, 1983:91.

${ }^{5} \mathrm{Li}$ CY, Yam LT, Crosby WH. Histochemical characterisation of cellular and structural elements of the human spleen. $J$ Histochem Cytochem 1972;20:1049-58.

- Crocker J, Curran RC. Quantitative study of the immunoglobulin-containing cells in trephine samples of bone marrow. J Clin Pathol 1981;34:1080-2.

${ }^{7}$ Crocker J, Jones EL, Curran RC. Study of nuclear diameters in non-Hodgkin's lymphomas. J Clin Pathol 1982;35:954-8.

${ }^{8}$ Crocker J, Jones EL, Curran RC. A quantitative study of alphanaphthyl acetate esterase-positive cells in non-Hodgkin's lymphomas and reactive lymph nodes. J Clin Pathol 1982;35: 1066-8.
- Crocker J, Jones EL, Curran RC. A quantitative study of alphanapthyl acetate esterase-positive cells in Hodgkin's disease. $J$ Clin Pathol 1982;35: 1301-6.

${ }^{10}$ Crocker J, Jones EL, Curran RC. A comparative study of nuclear form factor, area and diameter in non-Hodgkin's lymphomas and reactive lymph nodes. J Clin Pathol 1983:36:298-302.

" Livesey EA, Sutherland FI, Brown RA, Beck JS, MacGillivray JB, Slidders W. Cytological basis of histological typing of diffuse Hodgkin's disease. Demonstration of an implied misnomer in the terminology of the Rye classification. J Clin Pathol 1978;31:551-9.

${ }^{12}$ Crocker J. The enzyme histochemistry of lymphomas. Cambridge: University of Cambridge. 1983. MD Thesis.

${ }^{13}$ Erslev AJ, Gabuzda TG. Pathophysiology of blood. 2nd ed. Philadelphia: W B Saunders Co, 1979.

14 Payne SV, Newell DG, Jones DB, Wright DH. The ReedSternberg cell/lymphocyte interaction. Ultrastructure and characteristics of binding. Am J Pathol 1980;100:7-24.

is Taylor CR. Hodgkin's disease and the lymphomas, vol 3. Quebec \& Eden Press Inc, 1979:178.

16 Gordon MH. Remarks on Hodgkin's disease. A pathogenic agent in the glands, and its application in diagnosis. $\mathrm{Br}$ Med J 1933;i:641-4.

${ }^{17}$ Coppleson LW, Factor RM, Strum SB, Graff PW, Rappaport M. Observer disagreement in the classification and histology of Hodgkin's disease. J Natl Cancer Inst 1970;45:731-40.

${ }^{18}$ Holman CDJ, Matz LR, Finlay-Jones LR, et al. Inter-observer variations in the histopathological reporting of Hodgkin's disease: an analysis of diagnostic subcomponents using Kappa statistics. Histopathology 1983;7:339-407.

Requests for reprints to: Dr J Crocker, Consultant Histopathologist, Department of Histopathology, East Birmingham Hospital, Bordesley Green East, Birmingham B9 5ST, England. 